\title{
Alternative Dispute Resolution
}

\section{乃目 Borut Stražišar}

Assistant Professor, B\&B Educational Institution, PhD in law. Address: 16a Letališka Str., Ljubljana SI-1000, Slovenia. E-mail: borut.strazisar@guest.arnes.si

\section{国国 Abstract}

Alternative dispute resolution (ADR) becomes a synonym for different techniques as alternative to the long and costly court procedure. Alternative dispute resolution became popular in the middle of 1990's. At first, it was seen as a tool for the reduction of court's backlogs. With the diminishing role of national chambers of commerce - as promoters of arbitrage courts - also the arbitrage became less and less popular among small and medium size enterprises. These processes were even more radical in ex-Socialist/Communist countries with no small and medium enterprises developed ${ }^{1}$. So, the new millennium with the developed IT infrastructure has brought out also new ideas about the society development. The Alternative dispute resolution is now presented as a procedure that is faster and cheaper than the court procedure. To avoid the negative sides of arbitrage more elements of court procedure were introduced (like role of experts, provisional measures...). To make Alternative dispute resolution more popular it was promoted as a procedure in which the parties can choose their own judge, produce their own law and even sell the risk of the possible decision. But the latest judgement of EU court in investment arbitrage ${ }^{2}$ could be the end of such approach. The main question is whether the arbitrage could be still an effective method of dispute resolution also for small and medium size enterprises. For the adequate answer the analysis of historical development of ADR should be seen. Through the historical development the essence of ADR could be explained. Submission is divided in three parts. Introduction presents the historical developments and logic behind ADR. Second part deals with goals and interests in ADR. Understanding the goals and interests helps in understanding the nature of disputes. The last part presents cases in which ADR could be still effectively used. The solutions presented is a synthesis of first and second part findings.

\section{O-1目 Keywords}

dispute; resolution; arbitrage; mediation; negotiation; international commercial arbitration

Citation: Stražišar B. (2018) Alternative Dispute Resolution. Pravo. Zhurnal Vysshey shkoly ekonomiki, no 3, pp. 214-233 (in English)

DOI: $10.17323 / 2072-8166.2018 .3 .214 .233$

1 There was also a lack of entrepreneur tradition and knowledge.

2 Judgment in Case C - 284/16 Slowakische Republik v Achmea BV - The arbitration clause in the Agreement between the Netherlands and Slovakia on the protection of investments is not compatible with EU law. 


\section{Introduction}

\section{History of ADR}

Arbitration is simply a usually (but not always) private process of adjudication in which parties in dispute with each other choose decision-makers (sometimes one, often a panel of three) and the rules of procedure, evidence, and decision by which their dispute will be decided. This is distinguished from mediation in which a neutral third party facilitates party negotiations to resolve a dispute, but does not decide the matters in conflict, and adjudication in which an officer of the state (usually a judge) decides a matter according to principles of law that are often (but not always) published and available for use as precedent by parties other than the principal disputants ${ }^{3}$. Much of the current outcry and controversy about the use of arbitration is lodged by those (principally on behalf of employees, consumers, and non-merchant contractors for services) who see arbitration being mandated in situations where parties to a contract, or litigants in a court, are being compelled to use arbitration because of a contract clause or court rule that the party probably did not fully understand or agree to ${ }^{4}$. As a result of the growth of international commercial interaction, the number of disputes has increased and arbitration is often considered to be the preferable method of dispute resolution for reasons of expediency, technical specialization, or in order to avoid potential bias that might be encountered in national courts.

First roots of alternative dispute resolution could be found in China in mediation (tiaojie). It has origins in Confucian ethics. Confucius taught that natural harmony should not be disrupted, and adversarial proceedings were the antithesis of harmony. Chinese mediation aims not only to respond to a conflict when it breaks out, but also to prevent it from happening. It is total quality management of a conflict. Mediation treats conflict as being necessarily evil, bad, or undesirable. So the mediation aims to resolve conflicts - bring the conflict to end in order to reach the state of harmony. This is consistent with the Chinese folk term for a mediator, shuo he ze, a person who speaks in harmonious words to smooth interpersonal relationships. Chinese mediator plays a role that combines the function of counsellor, educator, pacifier, unifier, problem solver, arbitrator, negotiator, litigant, therapist and consultant. The mediator is usually a person who is regarded as an authority in the community. If either of the disputants refuses to accept the words of mediator, the mediator will not only "lose face" in front of the two disputants,

\footnotetext{
${ }^{3}$ Menkel-Meadow C. Ethics Issues in Arbitration and Related Dispute Resolution Processes: What's Happening and What's Not // University of Miami Law Review. 2000, vol. 56, p. 949.

${ }^{4}$ Ibid. P. 950.

${ }^{5}$ Nesheiwat F., Khasawneh A. The 2012 Saudi Arbitration Law: A ComparativeExamination of the Law and Its Effect on Arbitration in Saudi Arabia // Santa Clara Journal of International Law. 2015, no 3, p. 443.
} 
but also in front of community and the state. The intention of mediation is to avoid the damage to empathy, sympathy, care, respect for others and modesty for self.

Wolaver describes that traces of arbitration could be found in ancient Greece and Rome $^{6}$. While arbitration probably antedates all the former legal systems, it has not developed any code of substantive principles, but is, with very few exceptions, a matter of free decision, each case being viewed in the light of practical expediency and decided in accord with the ethical or economic norms of some particular group ${ }^{7}$.

In ancient Greece in the settlement of disputes between individuals the only concern of authority was the avoidance of disruptive friction between its subjects. The reciprocity principle didn't make peaceful resolution of conflicts. The use of mandatory reasoned arbitration is illustrated by Herodotus' report that the Persian Empire imposed arbitration procedures on the Ionian cities to settle their differences. Xenophon points out the case where Persians pushed the Armenians and Chaldeans to reach agreement about unused land and thus creating win-win situation. On the other case Xenophon point out that the cases of not voluntary exchange aren't just ${ }^{8}$.

The principle of arbitration could be found in Talmud in the book dealing with contracts, partnerships and found objects. Talmud in this book explains cases where portions established by will sum to more than total available. Talmud recognizes that different persons can have the rights that are equally valid but mutually inconsistent. To resolve such problem the principle of fairness should be used. And this can be done only through arbitration

In fact, arbitration that applies Shari'a as its foundation and governing law is endorsed in the Qur'an. Arbitration (or tahkim), often in the sense of an amiable compositeur, has played an integral role as a means of resolving disputes in pre-Islamic Arabia, and the role of arbitration was also acknowledged in all four schools of Islamic legal tradition and has continued to be of widespread use in the region thereafter, including in the earliest disputes between the Saudi Arabian government and foreign oil companies ${ }^{9}$.

Customary laws emerge spontaneously as a consequence of cooperation induced by reciprocities. Reciprocity, in fact, provides the basis for recognition of duty or obligation under customary law. Cooperation does not require collective (governmental) action. Furthermore, the rules of obligation recognized under all

${ }^{6}$ In Heraldus' Animadversiones there is described a court of reconcilement that existed among the Greeks.

7 Wolaver E. The Historical Background of Commercial Arbitration // University of Pennsylvania Law Review and American Law Register. 1934, no 2, p. 132.

${ }^{8}$ Lowry S. The Economic and Jurisprudential Ideas of the Ancient Greeks: our =Heritage from Hellenic Thought. Ancient and Medieval Economic Ideas and Concepts of Social Justice. S. Lowry and B. Gordon (eds.). Leiden: Brill, 1998, p. 11.

${ }_{9}$ Nesheiwat F., Khasawneh A. Op. cit. P. 444. 
the customary law systems that have existed have always focused on individual rights, including the right to private property ${ }^{10}$.

Medieval mercantile law was customary law enforced by the merchants themselves, and it was applied even-handedly to foreign merchants and domestic merchants alike.

Why would someone pay a fine or pay off any debt if the coercive power of the state did not exist to force payment? The answer is basically the same as for the question of why someone, particularly someone guilty of an offense, would submit to arbitration in the first place-ostracism and boycott sanctions would convince many to pay their debts11.

It is very common to say that commercial arbitration had its beginning with the practices of the market and fair courts and in the merchant gilds. It is true the gild merchant had wide grants of power as to trade. They were monopolistic in character and, in many cases, the right to trade in a borough depended upon membership in a chartered gild. They took active part in the government of the town, though their chief function was the protection of merchant privileges, guarding not only the local guildsman's interest but also that of town traders who had sought the markets of other towns. The gild was a part of the borough government "whose duty was to maintain and regulate the trade monopoly"12.

The suggestion that the gilds maintained boards of arbitration for the benefit of members is not borne out by the facts. Although the evidence is very meagre it is reasonably certain that the gild developed its own court to which members came not voluntarily but by order and summons. In cases involving debt and covenant they were, in many cases, courts of original jurisdiction ${ }^{13}$.

The practice of giving penal bonds to enforce engagements was very common. It was usually the practice to put the bond at a high figure as a means of insurance of performance. The validity of the bond depended on its seal and when the obligor revoked the arbitration authority, the bond became enforceable ${ }^{14}$.

Rolls of St. Ives (1110-1250) shows that mercantile court was indeed a state court. The St. Ives documents show that such coercive power-to enforce decisions, to collect damages, and to assess fines-was exercised routinely. Indeed, in the context of thirteenth-century legal theory, there could have been little dispute about such questions; these powers lay very clearly in the hand of the abbot of Ramsey. The court was part of the abbey's patrimony, which included the manor

${ }^{10}$ Benson B. Enforcement of Private Propeny Rights in Primitive Societies // Journal of Institutional and Theoretical Economics.1988. no 4, p. 772.

${ }^{11}$ Ibid.

12 Wolaver E. Op. cit. P. 133.

13 Ibid. P. 134.

${ }^{14}$ Ibid. 
of Slepe in which the village was located. The residents of St. Ives were largely of villain status and owed tenurial obligations to the abbey. The abbot therefore had direct, personal jurisdiction over the many residents of St. Ives who appear in the court rolls, and who came before the fair court as before the court of their lord ${ }^{15}$.

The executive authority of the abbot over the fair, so well established in theory, was also confirmed in practice. The officers of the fair court-the steward, the bailiffs, and the clerks-were appointed by the abbot or by his representatives. The court was held in the abbot's own administrative buildings, and the fines and amercements paid in the fair court went to the abbot's treasury ${ }^{16}$.

It was a feature of $13^{\text {th }}$ century practice, however, that despite the development of juridical concepts, parties tended to refer disputes to arbitration under a multijurisdictional commission to act as arbiter, arbitrator and amicable compositor, suggesting that the distinctions under discussion were those which struck jurists as important than those which were necessarily relevant in practice. When a submission was made the parties would not necessary be sure or indeed care whether the resolution was achieved in the form of an arbitrium or a mere composition, and by deploying the widest form of commission they permitted the most appropriate form of disposal to be used in the light of the arbitration ${ }^{17}$.

Originally conceived as a means to resolve commercial disputes among merchants during the medieval period, arbitration thrived as the preferred dispute resolution mechanism in specialized, self-regulating communities. Merchants were interested in a system that would resolve disputes (1) quickly (so they could leave the fairs) and (2) in accordance with industry standards (to facilitate relationships among the parties). Thus, self-regulating communities, like merchants in the seventeenth and eighteenth centuries, adopted an arbitral system to resolve disputes. Traditional arbitration, unlike litigation, empowered these disputants to appoint a disinterested third party who was an expert in the industry to resolve the dispute in accordance with understood customary norms. The arbitral process, with its lack of formalism, provided the swift results the parties desired. Moreover, the arbitral system ensured finality, also essential to facilitating continuing relationships, by obtaining the parties' agreement to abide by the arbitrator's resolution of the claim ${ }^{18}$.

${ }^{15}$ Sachs S. From St. Ives to Cyberspace: The Modern Distortion of the Medieval 'Law Merchant' // American University International Law Review. 2006, no 5, p. 685.

${ }^{16}$ Ibid.

${ }_{17}$ Godfrey M. Arbitration in the Ius Commune and Scots Law // Roman Legal Tradition. 2002, no 2, p. 122.

${ }_{18}$ Cole S. Curbing the Runaway Arbitrator in Commercial Arbitration: Making Exceeding the Powers Count. 2015. Available at: // http://works.bepress.com: http://works.bepress.com/sarah_cole/2/ (accessed: 2.02 .2016$)$ 
Interestingly, even if the parties had not agreed that the arbitrator's decision was final, judicial involvement would nevertheless have been unnecessary to ensure enforcement of most arbitration agreements or awards because both parties had an incentive to avoid self-serving behaviour. The amount in controversy tended to be relatively small, meaning that the value of the parties' ongoing relationship, as well as the reputational interest of each party within the industry, vastly outweighed the stakes at issue in any particular case. Thus, parties willingly abided by arbitration agreements and decisions in order to preserve their relationship and their respective reputations, and, accordingly, to protect their livelihoods ${ }^{19}$.

As we see from the history of arbitration the background of arbitration has changed through time. So today arbitration has almost nothing to do with the arbitration in medieval times. Even today the term arbitration as a dispute resolution, has totally diverse background in different countries. Present seeking of efficient and cheap way of dispute resolution has nothing to do with arbitration procedure. The answer is connected with:

social position of organization under the auspices of it operates the arbitral court;

relation of arbitral court to state organization (true NGO, quasi NGO or governmental organized NGO);

relation of parties to arbitral court (internal or external arbitration).

\section{Logic Behind Alternative Dispute Resolution}

Before proceeding on logic behind alternative dispute resolution, one terminological question should be resolved. Term "alternative dispute resolution" is misleading and inappropriate. Not all mechanisms, enumerated by legal theory, are really alternative or really dispute resolution. Merriam Webster dictionary defines adjective alternative in three different meanings:

offering or expressing a choice;

not usual or traditional;

existing or functioning outside of the established society ${ }^{20}$.

Negotiations or even mediations could not fall within term alternative in none of above three meanings. Indeed, they represent a contractual obligation to settle disputes peacefully and amicable. So, mediation is one of the ways to settle dispute amicably before going to court or arbitral court. Both are traditional, usual and exist form history within the society. Problematic is also the word dispute. Webster dictionary defines verb dispute in three meanings:

19 Ibid.

20 Webster M. Alternative. 2016. Available at:// http://www.merriam-webster.com/dictionary/alternative (accessed: 17.07.2016) 
to say or show that (something) may not be true, correct, or legal;

to argue about (something);

to fight in order to take control of (something) ${ }^{21}$.

Real disputes have their roots in problems of contractual implementation. But could we really talk about dispute before the procedure of adjudication? Preadjudication procedure actions are targeted to resolve the problem of contractual implementation and to find new common solution. So technically speaking it's not a dispute, it's a contractual problem. Solving the problem means also the preparedness of both parties to discuss the contract as whole. On the other hand, dispute means orientation only on one problem. There is no preparedness of both parties to discuss the contract as whole. Thus it would be more appropriate to talk about non-adjudication conflict solving (NACS). The only case in which we could talk about alternative dispute resolution are arbitral and state courts. The choice for arbitral court excludes the state court and vice versa. As we'll see forward, different ways of problem/dispute solving/resolution have different background and thus require different approach.

Negotiations are the first mechanism listed on the list how to solve conflict. Even if they are the oldest way to resolve conflicts, law is almost tacit about them. "Negotiation" is derived from the Latin neg (not) and otium (leisure or ease). Hence, the word "negotiation" reflects the inherent tension-not leisure-within the activity ${ }^{22}$. Walton and McKersie suggested that negotiation denotes "...the deliberate interaction of two or more complex social units which are attempting to define or redefine the terms of their interdependence"23. Winning in negotiations should not be defined in terms of defeating the other side, but rather in terms of achieving own objectives. Competition is part of negotiation, but so is cooperation. Negotiation involves both give and take. The other party in the negotiation is not one's adversary, but one's partner. Or it should be called counterpart ${ }^{24}$. Conflicts escalate because of naive realism. Negotiations are taxing for participants in part because information is incomplete and uncertain, and a common strategy to reduce informational complexities is for people to act as naive realists: People assume that the world is as they perceive it; that other people view the world in that very same way ${ }^{25}$. American negotiation theory highlights "interests" as a key component of negotiations. According to this theory, people negotiate to fulfil their

${ }^{21}$ Ibid.

${ }^{22}$ Cohen J. Adversaries? Partners? How about Counterparts? // Conflict Resolution Quarterly. 2003, no 4 , p. 430.

${ }^{23}$ See for details: Walton R. and McKersie R. A Behavioral Theory of Labor Negotiations. Beverly Hills: Sage Publications, 1965.

${ }^{24}$ Cohen J. Op. cit. P. 431.

${ }^{25}$ De Dreu C. PACT against Conflict Escalation in Negotiation and Dispute Resolution // Current Directions in Psychological Science. 2005, no 3, p. 149. 
interests. Getting to Yes, the classic American negotiation text, urges negotiators to "focus on interests, not positions." Interests are commonly thought to include substantive, procedural, and psychological interests ${ }^{26}$. Marc Galanter warns that naming negotiation as alternative dispute resolution is misleading because it implies that negotiation is infrequent, new, unproven, and marginal ${ }^{27}$. He points out that negotiation is always a part of litigation. It's a strategic pursuit of a settlement through mobilizing the court process - litigotiation ${ }^{28}$. Condlin defines three processes within negotiation:

assessment - a negotiator identifies the principal meaning of an adversary's communication, determines whether it accurately predicts what the adversary will do, and measures the importance the adversary attaches to the predicted behaviour. Call these the questions of meaning, trustworthiness, and valuation;

exchange - is the process of offer, concession, and, usually agreement. These manoeuvres occur in sequence, and collectively are referred to as the concession pattern. Exchange takes place within a bargaining range, a set of points located on a spectrum of overlap between the smallest amount one side will accept and the largest amount the other side will give before refusing to settle;

persuasion - is the process of convincing an adversary to view a matter in dispute favourably to oneself. It can take the form of threat, appeal, and argument. Threat is the prediction that one will harm another unless the other performs some specified action within his control. Appeal is the request that an adversary make a gratuitous concession and is similar to the practice in animals of going "bellyup" when faced with certain defeat by a more powerful enemy. Argument is the invocation and reasoned elaboration of authoritative norms-rules, policies, and principles-to support a negotiation position or to rebut an adversary's position ${ }^{29}$.

As we could see, the process of negotiation has little to do with legal norms and legal arguments. The whole negotiation process is more about parties' interests, expectations and concessions' limits. Legal norms post only the border for negotiations. Parties could not negotiate about cases that violate the cogent legal norms or it would be amoral.

Next mechanism in conflict solving is mediation. West's Law Encyclopedia defines mediation as "A settlement of a dispute or controversy by setting up an independent person between two contending parties in order to aid them in the

${ }^{26}$ Barkai J. Cultural Dimension Interests, Dance of Negotiation, and Weather Forecasting: A Perspective on Cross-Cultural Negotiation and Dispute Resolution // Pepperdine Dispute Resolution Law Journal. 2008, no 3, p. 403.

27 Galanter M. Worlds of Deals: Using Negotiation to Teach about Legal Process // Journal of Legal Education. 1984, no 2, p. 268.

${ }^{28}$ Ibid. P. 267.

${ }^{29}$ Condlin R. Cases on Both Sides: Patterns of Argument in Legal Dispute-Negotiation // Maryland Law Review. 1985, no 1, p. 65. 
settlement of their disagreement ${ }^{30}$. In International Law, mediation is the friendly interference of one state in the controversies of nations. It is recognized as a proper action to promote peace among nations." Mediation derives from $14^{\text {th }}$ century Medieval Latin word mediationem and means "a division in the middle," noun of action from past participle stem of mediare "to halve; to be in the middle" 31 . Mediator is a person who has no socially legitimate authority to render a decision but his mandate is to settle a case. Mediation range between bargaining and therapy ${ }^{32}$. The process of mediation should be seen as extension of negotiations. Mediation and mediators help disputing parties to:

open or improve communications between or among them;

establish or build more respectful and productive working relationship;

better identify, understand, and consider each other's interests, and concerns;

propose and implement more effective problem-solving or negotiation procedures; recognize or build mutually acceptable agreements ${ }^{33}$.

Mediators are independent. They also commonly do not have predetermined, biased, or fixed opinions or views regard how the dispute should be resolved, but they are able to look at all parties' issues, needs, interests, problems and relationships in a more objective, impartial, or "multipartial" manner than can participants themselves. It's expected form mediator to be impartial and neutral person, although the neutrality is hard to define and to measure. Mediators has often the view of neutrality-as-impartiality. "Impartiality" is equivalent to the absence of feelings, values, or agendas; "bias" is to be avoided-it is a strong opinion, value, feeling, or agenda. The mediator's goal is either to dismiss their opinions, values, feelings, and agendas or to separate them from the mediation process ${ }^{34}$.

Mediation offers some clear advantages over adversary processing: it is cheaper, faster, and potentially more hospitable to unique solutions that take more fully into account nonmaterial interests of the disputants. It can educate the parties about each other's needs and those of their community. Thus, it can help them learn to work together and to see that through cooperation both can make positive gains. One reason for these advantages is that mediation is less hemmed-in by rules of procedure or substantive law and certain assumptions that dominate the adversary process ${ }^{35}$. In most mediations, the emphasis is not on determining rights or interests, or who is right and who is wrong, or who wins and who loses

30 See: West's Encyclopedia of American Law. 2nd ed. London: Gale Group, 2008. P. 505.

${ }^{31}$ Harper D. (2001-2016). Online Etymology Dictionary. Available at: http://www.etymonline.com/ index.php?term=mediation (accessed 16.07.2016).

32 Silbey S., Merry S. Mediator Settlement Strategies // Law \& Policy, 1985, no 1, p. 7.

33 See for details: Moore C. The Mediation Process. San Francisco: John Wiley and Sons, 2014.

${ }^{34}$ Cobb S., Rifkin J. Practice and Paradox: Deconstructing Neutrality in Mediation // Law \& Social Inquiry. 1991, no 1, p. 35.

${ }_{35}$ Riskin L. Mediation and Lawyers // Ohio State Law Journal. 1982, no 1, p. 29. 
because of which rule; these would control the typical adjudicatory proceeding. The focus, instead, is upon establishing a degree of harmony through a resolution that will work for these disputants. A danger inheres in this illegal character: individuals who are not aware of their legal position are not encouraged by the process to develop a rights-consciousness or to establish legal rights. Thus, the risk of dominance by the stronger or more knowledgeable party is great ${ }^{36}$.

We can conclude that mediation follows more or less the same logic a negotiation. Goal is to solve conflict with the help of third person. Goal is to reach a new agreement, acceptable from both parties and thus overcome the existing conflict. Legal norms are pushed into background. Parties are seeking how to resolve conflict not how to legally protect their interests.

Arbitration is the last method of conflict resolution and also adjudication. It's a subject of different scholarly articles and books. In last years there is a strong movement for its promotion. To make arbitration efficient states are changing their laws and bylaws ${ }^{37}$. Arbitration courts change their procedural codes towards simplified court procedures. Arbitral procedure wants to become cheaper, faster and more efficient than court procedure. Indeed, arbitration is seen as efficient version of privatized courts. In this changeable world the question about essence of arbitration should be posted again. What is arbitration? The word arbitration has roots in Latin arbitrari - "decided by one's own discretion or judgment". It should be made the distinction between the "arbiter" deciding according to the law, and the "arbitrator" and "amicable compositor" deciding according to justice ${ }^{38}$.

Parties created arbitration to resolve disputes effectively, efficiently and at a lower cost than they could achieve through litigation. While arbitration is similar to litigation in that a neutral third-party resolve the dispute, it differs in several important ways, including that the parties design the process and control (at least in theory) the issues and law the arbitrator can consider and the remedies she can order. In addition, in a typical arbitration, parties trade the right to challenge the substance of the decision-maker's ruling in exchange for a fast and relatively final resolution of the issue. Narrow judicial review of arbitration awards made sense historically because parties wanted their disputes resolved according to norms and customs, rather than laws ${ }^{39}$.

36 Ibid. P. 30 .

37 Despite being a relatively recent chapter in arbitration, thus, less common than interim measures in the context of civil court proceedings, interim measures are becoming increasingly important in arbitration practice. Rules on emergency relief were aimed at responding to the parties' demand to have the choice to avoid approaching State courts with interim relief requests before the formation of the arbitral tribunal.

${ }^{38}$ Godfrey M. Arbitration in the Ius Commune and Scots Law. Roman Legal Tradition, 2002, no 2, p. 122.

39 Cole S. Op. cit. Available at: http://works.bepress.com: http://works.bepress.com/sarah_cole/2/ (accessed: 2.02 .2016$)$ 
Moreover, modern commercial disputes might have purely commercial aspects, or purely legal aspects, or a combination of both. If legal questions are at issue, merchants would have an interest in obtaining expanded judicial review of arbitration awards because arbitrators are generally considered experts in particular industries but not in the law. In other words, merchants might want to increase the predictability of results where legal issues are central to the dispute while still taking advantage of some of arbitration's benefits, such as speed and efficiency ${ }^{40}$.

Like other sellers, courts and arbitration institutions provide bundles of services to their customers - in this case, bundles of dispute resolution procedures to the parties in a dispute. Courts provide the default bundle, but parties can opt instead for arbitral procedural bundles that vary according to the applicable arbitration rules chosen by the parties. Scholars traditionally assume that sophisticated parties make a single choice between courts and arbitration based on the bundle of dispute resolution services that seem most appealing ex ante. As with the literature on bundling generally, however, legal scholars are increasingly focusing their attention on the unbundling of court and arbitral procedures - that is, the ability of parties to contract for à la carte or customized dispute resolution procedures in court and arbitration. Carve-outs and carve-ins are mechanisms by which parties choose between court and arbitral bundles of procedures on a claim-by-claim or remedy-by-remedy basis. By using carve-outs and carve-ins, parties can obtain a more carefully calibrated unbundling of procedure than an arbitration clause or forum-selection clause alone would provide, but at a much lower overall cost than the parties would incur by contracting for individual procedures. What often results is a sort of middle ground for bundling of procedural rules: parties choose among pre-set bundles of dispute resolution services, but unbundle the circumstances where any given dispute resolution bundle will be used ${ }^{41}$. Arbitration, in short, is a trade-off in which the parties agree to exchange the benefits and risks of dispute resolution under the formal law for the benefits and risks of dispute resolution in a less formal setting ${ }^{42}$.

International commercial arbitration, while sometimes cited as an example of private ordering, is in fact-a hybrid case-with important elements of public involvement supplementing the use of a private decision maker. International commercial arbitration, as distinguished from trade association arbitration, is nonspecialized arbitration between private parties involved in international commercial transactions. Parties to international arbitration agreements reject the option of having their dispute resolved under privately developed commercial rules, the so-

40 Ibid.

${ }^{41}$ Drahozal C., O’Hara O'Connor E. Inbundling Procedure: Carve-Outs From Arbitration Clauses // Florida Law Review. 2015, no. 5, p. 945.

${ }^{42}$ Reuben R. First Options, Consent to Arbitration, and the Demise of Separability: Restoring Access to Justice for Contracts with Arbitration Provisions // SMUL Rev. 2003, no 56, p. 819. 
called new Law Merchant or lex mercatoria. Instead, they choose to have their dispute resolved under publicly created laws. Moreover, unlike parties in trade association arbitrations, parties in international commercial arbitrations often turn to the courts for aid in enforcing awards. Too often, international arbitration is grouped with trade association arbitration in ways that blur the important distinctions between the two ${ }^{43}$.

Trade association arbitration is most likely to be used for transactions in simple goods, although less likely in international transactions involving greater distances than domestic transactions. International commercial arbitration is the more likely choice for international transactions, except in cases in which the applicable law is clear or emergency relief is likely to be needed. In such cases, parties are more likely to choose litigation in national courts ${ }^{44}$.

We must distinguish two types of arbitration:

rights arbitration - refers to situations covered by pre-existing rules or customs. When a dispute has arisen because the rules are unclear, the arbitrator makes a judgement about the meaning of the rules, and in this way, decides the parties' rights;

interests arbitration - there are no pre-existing rules. Judgements are made on the parties' interests, i.e., the relative benefits each would receive ${ }^{45}$.

In the case of rights arbitration the arbitrator must clarify the meaning of the rules or in some cases resolve a contradiction among prevailing rules. In the interest arbitration the decision will be based on a conception of fairness, or on the relative powers of the two sides in order to make a stable workable agreement. The interests arbitrator is a fast and safe substitute for the barging process ${ }^{46}$.

Informality of arbitrage is a two-edged sword. Because arbitration permits parties to resolve their disputes without the constraints of law, it has the potential to be faster and less expensive than traditional litigation. It also offers the possibility of better decision making, as arbitration awards are generally made by persons whom the parties agree upon, often because of the arbitrator's sophistication in the subject matter of the dispute. Moreover, unfettered by rules of evidence or procedure, arbitral decisions can be based on whatever evidence the parties wish to put before the arbitrator, including industry customs and practices and other applicable but non-legal norms. However, the absence of legal standards can translate into gross substantive and procedural injustices, particularly when there are severe power imbalances between the parties, and the absence of substantive

${ }^{43}$ Drahozal C. Private Ordering and International Commercial Arbitration // Penn State University Law Review. 2009, no 4, p. 1032.

${ }^{44}$ Ibid.

45 O’Neill B. A Problem of Rghts Arbitration from the Talmud // Mathematical Social Sciences. 1982, no 2, p. 345.

${ }^{46}$ Ibid. P. 346. 
judicial review worsens the situation by making capricious awards essentially uncorrectable. This problem is exacerbated by the fact that arbitrators, unlike judges, have economic incentives with respect to their caseloads that can affect their judgment in individual cases, making them perhaps more favourably disposed toward "repeat players" than "ones hotters." ${ }^{7}$

Access to arbitration should not be confused with "access to justice" more generally. Adopting arbitration as the final forum is consensual and a party has the choice whether or not to agree to this form of dispute resolution. If cost pressure is a concern for a party then it should be taken into account before an agreement to arbitrate is made. Of course, the cost of pursuing a dispute and the potential for an adverse costs award is likely to be as much a concern in relation to those contemplating litigation as it is for arbitration ${ }^{48}$.

\section{Goals and Interests in ADR}

As seen from the presented historical development non-judicial dispute resolution was chosen by the parties due to different reasons and local markets demands. Nevertheless, each historical period and each local market custom and demand contribute a small stone to a mosaic of $20^{\text {th }}$ century arbitral procedures and courts. Changes in local chambers of commerce (transition from mandatory to voluntary membership, no formal control of local market...), globalization of commerce (no need form import-export companies, expanding number of subjects in international trade...), modern banking systems (enabling fast money transfer) and abolition of trade barriers place in front of dispute resolution new challenges.

Contrary to the present stand, medieval merchant courts were far away from the modern perception of arbitral court. They were a part of borough authority. Notwithstanding this fact they introduced some key principles of ADR.

Firstly, they promote customary law and not the state (city) law. The introduction of Lex Mercatoria set the solid foundation for the medieval "international" trade. Because it was a general customary law, it was accepted from all the merchants and also understood by all merchants. Malynes wrote: "Every man know eth, that for Manners and Prescriptions, there is a great diversity amongst all Nations: but for the customs observed in the course of traffic and commerce, there is that sympathy, concordance, and agreement, which may be said to be of like condition to all People, diffused and spread by right reason, and instinct of nature consisting perpetually. And these Customs are properly those observations which Merchants maintain between themselves, and if these be separated from the Law

47 Reuben R. Op. cit. P. 820.

48 Williams D., Walton J. Costs and Access to International Arbitration // Journal of the Chartered Institute of Arbitrator. 2014, no 4, p. 432. 
of Nations, the remainder of said Law will consist of but few points." The $19^{\text {th }}$ Century brought modern civil codifications (French Code Civil 1804, Austrian Allgemeines bürgerliches Gesetzbuch, ABGB 1811, Montenegrin Opšti imovinski zakonik in 1888 and German Bürgerliches Gesetzbuch in 1900) that accepted also some customs used in everyday life. Nevertheless, the trade customs were part of commercial life till the 1980 's. Process of industrial globalisation and international trade expansion (with more and more complex contracts) caused the wane of trade customs and also the position of arbitration courts. If earlier that courts were a successors of merchant courts and interpreters of customary law, after 1980's became as an alternative to state courts. On the other hand, also the state courts, to the virtue of modern civil codes, gain the authority to judge on the basis of customary law (if the parties of contract include customary law as governing law) Mentioned change destroyed the key concept of customary law - the concept of full autonomy and expression of self-regulation ${ }^{49}$. Thus in present life most of agreements in international trade are governed by state laws and not by customs.

Second, even though the medieval merchant courts in UK (but not in other continental Europe city states) were a part of borough's governing authority, they promote the basic principle - essence over procedure. There were some procedural rules, but all it was in the hand of arbiter ${ }^{50}$. Merchants brought disputes to arbiters mainly for time and financial reasons $\mathrm{s}^{51}$. Procedural rules were always connected to time consuming and also to the lawyers ${ }^{52}$. Thus merchants used this way of dispute resolution to resolve disputes arising from the day to day trade. They were questions about fulfilment of rights and obligations under customary law. Contrary to state regulations, customary law is more open to interpretation. Rules aren't so exact - they mostly deal with principles (ethical and moral). Main part of decision procedure was also interpreting basic trade principles. Using arbitration, merchants got a quick decision (and thus possibility to move to a fair in another city) not damaging further trade relations. Main interest of the parties was achieving the execution of business relation and not avoiding the proper obligations. We can see the use of arbiters for both type of arbitrage: rights and interests. Due to the openness of customary law the same rule could be used for long time - only the interpretation was changed through time. The use of customary rule could be

49 It's a kind of paradox. The 1980's and 1990's brought a policy of wide self-regulation in different fields of human activities (e.g. IT, medicine...). On the other hand, national and international chambers of commerce and "classic industry" moved out of self-regulation.

50 See Kotruljević B. Della mercatura et del mercante perfetto. Dubrovnik, 1458.

51 Ibid.

52 Koturljević in the chapter »O mijestu primjernem za trgovca (About the right place for the merchant) " wrote:"...in the towns that commerce is ruled by Justinian Law (i.e. state law) there are also lawyers. And as it is known the lawyers are the main enemy of merchant's sack...” 
widened or narrowed - depending of the time and space component. Over all the customary law was sc. divine law - equal justice and fairness ${ }^{53}$.

Third, aim of medieval merchant courts was also to gain execution of award. The same goal was pursued also in the medieval systems of arbiters in Mediterranean area. Although the problem of non-execution is not an invention of modern society ${ }^{54}$. This goal was achieved through two mechanisms:

fear of place-ostracism and boycott sanctions;

penal bonds, set in case for non-execution of merchant court's award.

First mechanism worked efficiently because of trade monopolies (so the borough market authorities decided about accession to local market) and small number of merchants (they were personally known). We found no historical data about the execution of penal bonds. But, considering the descriptions of life of medieval merchant in Koturljević's work, most merchants were life dependent from daily trade. So, execution of the award was necessary for merchant to gain the daily payments and moving to other fair location ${ }^{55}$.

Fourth, there was no clear distinction between arbitration and non-arbitration procedure. In Kotruljević's work in the chapter "About the merchant's personality" we could find the guidance about setting possible disputes amicably ${ }^{56}$. So arbiter main goal was to find a solution acceptable for both parties. This could be reached through various mechanisms - from counselling, through a way of mediation to final adjudication. It was up to arbiter to choose the right "tool" to settle the dispute. Merchants choose arbiter because of his ability and knowledge how find the solution for the dispute. It was not important whether the settlement was reached on the basis of "wise man's advice" or on adjudication. We can't ignore the fact that even in that time the arbiter was chosen when the parties were unable to settle their dispute among themselves. As we can see from the China case, the wise arbiter plays many roles with one goal - to effective resolve the conflict. Main goal though was not to find the solution itself but to overcome relation's conflict among the parties. We could see this approach in interest arbitration or in the cases that different persons can have the rights that are equally valid but mutually inconsistent

And last but not least, as we see it from historical development described at the beginning of this submission, the parties had chosen arbiter because of his professional and moral authority. Both authorities were part of arbiter's day-to-day life. Professional authority was gained through his professional activity. It showed

${ }^{53}$ Malynes talks about common sense and justice. He points out that state law is in some cases unjust. So, the Lex Mercatoria allow to find the solutions that are just and in accordance with divine law.

54 The fact is that non-execution was also a big problem for medieval merchants. Benedikt Kotruljević wrote a special chapter titled "On execution".

55 Kotruljević B. Op. cit.

${ }^{56}$ Due to the preservation of merchant's good reputation. 
his capability to work in certain professional field and that his capability was respected and recognized by other professionals from the same profession. Such capability was not limited to good professional work but also to his attitude to the work done and towards others in the same profession. From today's standing we could talk about extraordinary, leading professional. Dealing with moral authority of arbiter is a bit trickier. Starting from Koturljević's work the moral aspect of merchant's personality was wider as we take into consideration today. Merchant's moral value was factor of different life relations:

merchant's personal relation to the product or service;

merchant's personal relation to other traders;

merchant's personal relation towards apprentice;

merchant's personal relation towards his family (and education of his family members);

merchant's personal relation towards his life.

So, the moral authority was a result of whole plethora of merchant's past and present relations seen in outside world or whispered in outside world. On the other hand the moral authority of merchant-arbiter was built on successful cases. Successful cases showed that parties respect and executes the given solution not only on the ground of professional reputation but also on the ground of moral reputation. If the arbiter was known as fair, impartial and righteous (that is a part of moral quality), then the parties didn't have ground to attack the given solution without reasonable professional arguments. And this is also the main logic behind arbitration. It's the decision of the parties to submit their dispute (or rather problem) to someone else's decision (or judgement). The parties didn't expect the legal solution (that was part of state courts system), rather they expected the professional working solution for their conflict. That was also the reason why in such procedures there were no lawyers. In this way arbiters could be creative and innovative to find the solutions that fit to each specific relation and thus neglected a possible intention to solve similar problems in similar way.

\section{Today's Trends and Possible Solutions}

International trade's demands (esp. speed of international trade) posts in front of its actor's new questions and challenges. Many old solutions were abandoned as archaic and improper for present time. Most "new age trade economists" have tried to persuade that new economic relations are different from old relations. If we read the work of Koutrljević we can see that in trade nothing has really changed. The logic of trade remained the same. The main ideas of merchant's role in market are still the same. The problem of non-execution of contractual obligations is still the same. The system of accountability remained the same (as the tool for the merchant to see whether he produces loses or profits). The only two things that have 
changed were speed and terminology. But the logic and intention is still the same as it was 1000 years ago.

Non-judiciary dispute resolution has been also a part of a whirl of mentioned changes. Invention of sc. alternative dispute resolution, recognizing arbitral awards as execution title, importing elements of civil procedure in arbitral procedures (remuneration of costs, extraordinary measures, court experts,...) shows us that that industry and commerce is trying to find a fast, not expensive and efficient system of dispute resolution. The main idea was to find an alternative to judicial system that was overloaded with time and money consuming protection of parties' rights within the civil procedure. On the other hand, such ideas were also the reflection of 1990's perception that state economy and state organizations are expensive, inefficient and also corrupted. So, the alternative dispute resolution was seen also as a project of privatization of state court system. And the proponents of such system had had all the arguments in their hand (civil procedure was costly, time consuming and - due to increase of court cases in many countries - a lot of cases were ended without judgement due the time reason).

The current legal framework for international arbitration was initiated by the Geneva Protocol in 1923 and Geneva Convention in 1927 and culminated in the signing of the United Nations Convention on the Recognition and Enforcement of Foreign Arbitral Awards in 1958 ("New York Convention"), the promulgation of the UNCITRAL Arbitration Rules in 1976, the adoption of the UNCITRAL Model Law in 1985 and the enactment of "modern" arbitration statutes in many developed jurisdictions from 1980 to the present day ${ }^{57}$.

The shiny era of international trade arbitration was ended in $2^{\text {nd }}$ decade of $21^{\text {st }}$ century. The international corporate community has become somewhat disenchanted with that particular mechanism because of concerns about rising costs, delays, and procedural formality ${ }^{58}$. As a result, parties are looking for other means of resolving international commercial disputes. So, the arbitration has lost the advantages that had attracted actors in international trade. Thus, mediation and conciliation was offered as an alternative to arbitration procedure. So, the industry is searching the way back to the roots of non-adjudication and mainly informal procedures. On the other hand, arbitral courts all over the world seek how to regain the past glory of arbitration and how to get clients (and their money) back under the veil of trade associations. This process is now two folded:

arbitral procedures are really becoming the alternative court procedures (only main difference - clients can choose judges and there is only one instance);

${ }^{57}$ Born G., Wendy M. Global Trends in International Arbitration. 2006. Available at: http://www. americanlawyer.com (accessed: 26.08.2016)

${ }^{58}$ Strong S. Beyond International Commercial Arbitration? The Promise of International Commercial Mediation // Washington University Journal of Law and Polity. 2014, no 4, pp. 11-39. 
promotion of institutional mediation and conciliation procedures within trade associations.

So the Western civilization stubborn persist on the difference between arbitration, mediation, conciliation and other forms of out-of-court dispute resolution. And thus the western legal theory in this field produced the artificial nonsense formal regulation of traditionally informal procedures. And mentioned nonsense had destroyed and will destroy the historically efficient mechanisms of out-ofcourt dispute resolution. Developments and final results in international trade dispute resolutions brought out the never ending legal dilemma of domestic law: is procedure the slave of material law or is material law the slave of procedure? We could advocate that on individual trader there is a wish to use procedural rules to abide the execution of obligation. But on international level the demand of capital returns the main principle is still "pacta sunt servanda." Without that principle international trade would be dead. Main players in international trade are aware of that fact and thus reverting from arbitral procedures to other less formal and more efficient procedures.

What could we do helping the international trade to find the lost treasure?

First, we should distinguish among adjudication and non-adjudication types of dispute resolution. Both types serve to the same purpose - resolution of conflict among parties. We should bear in mind that under the rules of FIDIC there is arbitral procedure that is quasi-adjudicative. Party who is not satisfied with the result of arbitration can still begin the court procedure. We could say that the basic distinction among both types of resolution is the content of decision. In adjudication procedures we are resolving disputes. In non-adjudication procedures we are resolving conflicts. Someone would argue that there is no difference between dispute and conflict. If we look to Merriam-Webster dictionary we could see the difference:

dispute - to say or show that (something) may not be true, correct, or legal; to argue about (something); to fight in order to take control of (something);

conflict - a struggle for power, property, etc.; strong disagreement between people, groups, etc., that results in often angry argument; a difference that prevents agreement: disagreement between ideas, feelings, etc.

The main difference is that in dispute there is a "battle line" and in conflict such "battle line" doesn't exist. So, the conflict resolving approach has more chances to bring the acceptable solution. The conflict approach allows accepting the compromise; the dispute approach allows only to accept one party's stand and thus leaving the other party disgruntled (and provoking new conflicts). Solution is that to the industry should be offered non-adjudication procedure as a part of conflict resolution. More activity should be done on informing the actors in industry how to deal with conflict instead how to deal with disputes. Or better, how to prevent that conflict arises in dispute. 
Second, the distinction among different types of conflict solution should be abolished. The main goal should be the elimination of conflict. So, it's on chosen arbiter (in the wider sense) what approach will chose. Nevertheless, the parties should still have the emergency exit in adjudication procedure in case that conflict resolution process would fail or not end in preferred way. With such exit parties would more willingly participate to find new solution for given conflict. On the other hand, such approach demands the development of two different types of arbitral courts:

with recognized adjudication procedures and recognized arbitral awards;

without adjudication procedures and arbitral awards recognized only after undersigning by both parties.

We could say that such solution will bring back the real distinction among private way of conflict resolution and official dispute resolution (which could be also private).

Third, formal procedures should be abolished and/or put in the hand of parties and arbiters. In this way the procedures would be faster and low cost again. As said, the main goal is elimination of conflict and not the lawyers' show.

Fourth, the prevention of conflict of interests for arbiters should be widely accepted. The policy of conflict of interests' prevention is warranty for equal treatment of both parties. In modern world the professional and moral authority could be always questioned. The parties chose the arbiter. With the selection of arbiter parties accept also his/hers professional and moral quality. In such system prevention of conflict of interests assures the equal and just treatment of both parties.

And last but not least - the efficient system for execution of reached deals should be introduced. As we have learned from the past, the fear from ostracism and boycott was the main factor that merchants were willing to execute arbitral awards. If we look to system of e-bay or Alibaba the same principle is valid also today. Buyers are more willing to trade with the seller with more positive responses or higher trusted rate. So, the sellers (and buyers) are trying to be fair and to gain higher grade. Higher grade and positive responses means also more business in the future. Such system could be accepted also in the field of non-adjudication way of conflicts" resolving. The following system could be introduced. The parties with the choice of arbiter would also undersign the agreement that in the case of non-execution of closed deal (within non-adjudication procedure) such case and names of the parties would be published on the public black list run by trade associations. The parties would be obliged to inform the arbiter about execution of accepted solution within three months after the successful ending of non-adjudication procedure. If there is case of non-execution, the arbiter is obliged to inform the trade association about such fact. 


\section{O-1 References}

Barkai J. (2008) Cultural Dimension Interests, Dance of Negotiation, and Weather Forecasting: A Perspective on Cross-Cultural Negotiation and Dispute Resolution. Pepperdine Dispute Resolution Law Journal , no 3, pp. 403-448.

Born G. \& Wendy M. (2006) Global Trends in International Arbitration. Available at: http:// www.americanlawyer.com (accessed: 26.08.2016)

Cole S. (2015) Curbing the Runaway Arbitrator in Commercial Arbitration: Making Exceeding the Powers Count. Available at: http://works.bepress.com: http://works.bepress.com/sarah_cole/2/ (accessed: 2.02.2016)

Drahozal C. (2009) Private Ordering and International Commercial Arbitration. Penn State University Law Review, no 4, pp. 1032-1050.

Drahozal C. \& O'Hara O'Connor E. (2015) Unbundling Procedure: Carve-Outs From Arbitration Clauses. Florida Law Review, no 5, pp. 1945-2006.

Galanter M. (1984) Worlds of Deals: Using Negotiation to Teach about Legal Process. Journal of Legal Education, no 2, pp. 268-276.

Ghibrazde N. (2015) Preclusion of Remedies Under Article 16(3) of the UNCITRAL Model Law. Pace Int'l Law Review, no 1, pp. 347-396.

Godfrey M. (2004) Arbitration in the lus Commune and Scots Law. Roman Legal Tradition, no 2, pp. 122-135.

Harper D. (2016). Online Etymology Dictionary. Available at: http://www.etymonline. com/index.php?term=mediation (accessed: 16.07.2016)

Lowry S. (1998). The Economic and Jurisprudential Ideas of the Ancient Greeks: Our Heritage from Hellenic Thought. T. Lowry \& B. Gordon (eds. ). Ancient and Medieval Economic Ideas and Concepts of Social Justice. Leiden: Brill, pp. 11-37.

Moore C. (2014). The Mediation Process. 4th ed. San Francisco: John Wiley and Sons. $590 \mathrm{p}$.

Petros F. (2009). Underlying Distinctions between ADR," Shimglina" and Arbitration. Mizan Law Review, no 1, pp. 105-133.

Silbey S. \& Merry S. (1985). Mediator Settlement Strategies. Law \& Policy, no 1, pp. 7-32. Strong S. (2014). Beyond International Commercial Arbitration? The Promise of International Commercial Mediation. Washington University Journal of Law and Polity, no 4, pp. 11-39.

Williams D. \& Walton J. (2014). Costs and Access to International Arbitration. Journal of the Chartered Institute of Arbitrators, no 4, pp. 432-442. 